\title{
Rancang Bangun Pendeteksi Gelombang Berdiri pada Kabel Koaksial Menggunakan Dioda Detector $1 \mathrm{~N} 4148$
}

\author{
Anisa Yulia Haryanti ${ }^{1}$, M. Nanak Zakaria ${ }^{2}$, Aad Hariyadi ${ }^{3}$ \\ 1,2 Program Studi Jaringan Telekomunikasi Digital, \\ Jurusan Teknik Elektro, Politeknik Negeri Malang, Indonesia \\ ${ }^{3}$ Program Studi Jaringan Teknik Telekomunikasi, \\ Jurusan Teknik Elektro, Politeknik Negeri Malang, Indonesia \\ $\underline{1 \text { anisaayuliaa.27@gmail.com, }}{ }^{2} \underline{\text { nanak_zach@ @olinema.ac.id, }}$ ㄹaadhariyadi@gmail.com
}

\begin{abstract}
In the coaxial transmission line, there is a theory of standing waves. Standing waves occur due to interference between one wave with another wave. Some institutions or colleges may not all have the equipment to observe the exact waveform of an electrical signal or commonly called an oscilloscope. One of them is Malang State Polytechnic. Therefore, in this study I want to make it easier for students, especially in the transmission line practicum course, to be able to describe the standing wave curve in coaxial cable. The results of the system implementation are carried out using an IC LED VU Display as a standing wave curve display where the generator functions as a signal input which regulates the predetermined input frequency and voltage. The results of the test of this system are that standing waves in

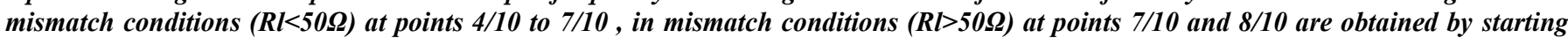
wave condition in match condition there is no reflected wave.
\end{abstract}

Keywords - Coaxial Cable, Detector Circuit, IC LED VU Display, T-connector.

\begin{abstract}
Abstrak - Dalam saluran transmisi koaksial, ada teori tentang gelombang berdiri (standing wave). Gelombang berdiri terjadi akibat adanya interferensi antara gelombang satu dengan gelombang yang lain. Beberapa institusi atau perguruan tinggi mungkin tidak semua memiliki peralatan untuk mengamati bentuk gelombang yang tepat dari sinyal listrik atau biasa disebut dengan osiloskop. Salah satunya yaitu Politeknik Negeri Malang. Maka dari itu, pada penelitian ini saya ingin memudahkan para mahasiswa, khususnya dalam mata kuliah praktikum saluran transmisi untuk dapat menggambarkan kurva gelombang berdiri pada kabel koaksial. Hasil penerapan sistem dilakukan dengan menggunakan IC LED VU Display sebagai tampilan kurva gelombang berdiri dimana generator fungsi sebagai masukan sinyal yang mana mengatur frekuensi dan tegangan input yang sudah ditentukan. Hasil dari pengujian sistem ini diperoleh gelombang berdiri dalam kondisi mismatch $(\mathrm{Rl}<50 \Omega)$ pada titik $4 / 10 \lambda$ hingga $7 / 10 \lambda$, dalam kondisi mismatch $(\mathrm{Rl}>50 \Omega)$ pada titik 7/10 $\lambda$ dan 8/10 $\lambda$ diperoleh dengan diawali kondisi gelombang dalam kondisi match tidak ada gelombang yang dipantulkan.
\end{abstract}

Kata kunci- Kabel Koaksial, Rangkaian Detector, IC LED VU Display, T-connector.

\section{PENDAHULUAN}

Penyampaian informasi dari suatu sumber informasi kepada penerima informasi dapat tersampaikan apabila ada suatu sistem atau media penyampaian yang menghubungkan komunikasi di antara keduanya. Jarak antara sumber informasi dengan penerima informasi sebagai penentu apakah memerlukan sistem transmisi yang sederhana atau lebih kompleks. Sistem transmisi bisa terdiri dari satu atau lebih media transmisi. Media yang digunakan dapat berupa media fisik (kabel) atau non fisik (nirkabel). Komponen yang sangat penting dalam sistem transmisi, baik media kabel atau nirkabel yaitu saluran transmisi. [1].

Saluran transmisi apabila dibedakan berdasarkan medianya, dibedakan menjadi 4 jenis, yaitu saluran transmisi dua kawat sejajar (two-wire transmission line), saluran transmisi koaksial (coaxial transmission line), microstrip dan stripline dan bumbung gelombang (waveguides). Tipe saluran transmisi yang dipakai pada aplikasi dari frekuensi rendah hingga frekuensi yang tinggi adalah kabel koaksial.
Kabel koaksial terdiri dari dua konduktor yang dipisahkan oleh material dielektrik. Bagian dielektrik umumnya menggunakan Polyethylene. Untuk aplikasi frekuensi tinggi biasanya menggunakan bahan teflon [1] [2].

Saluran transmisi koaksial merupakan saluran transmisi dimana media yang digunakan yaitu kabel koaksial. Kabel koaksial ada beberapa macam, salah satunya kabel koaksial

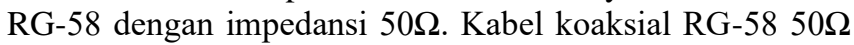
merupakan jenis kabel yang digunakan sebagai saluran transmisi untuk sinyal frekuensi radio. Frekuensi dibagi menjadi beberapa range, mulai VLF (Very Low Frequency) hingga EHF (Extremely High Frequency). Untuk jenis kabel koaksial RG-58 $50 \Omega$ dapat digunakan untuk rentang HF (High Frequency) dengan frekuensi 3-30 MHz. Dalam saluran transmisi koaksial, ada teori tentang gelombang berdiri (standing wave). Gelombang berdiri terjadi akibat adanya interferensi antara gelombang satu dengan gelombang yang lain.

Beberapa institusi atau perguruan tinggi mungkin tidak semua memiliki peralatan untuk mengamati 
bentuk gelombang yang tepat dari sinyal listrik atau biasa disebut dengan osiloskop. Salah satunya yaitu Politeknik Negeri Malang. Maka dari itu, pada penelitian ini saya ingin memudahkan para mahasiswa, khususnya dalam mata kuliah praktikum saluran transmisi untuk dapat menggambarkan kurva gelombang berdiri pada kabel koaksial. Dari hal tersebut, mahasiswa dapat menggambarkan gelombang berdiri pada kabel koaksial dengan memanfaatkan diode detector 1N4148 dan IC LED VU Display (LM3915) yang akan digunakan adalah untuk mendeteksi dan dapat mengetahui gelombang berdiri pada kabel koaksial dengan sudah diketahui terlebih dahulu panjang gelombangnya (1/10 lamda, 2/10 lamda, dan seterusnya) dan frekuensi pada generator fungsinya. Maka dari permasalahan tersebut dapat digunakan judul "Rancang Bangun Pendeteksi Kurva Gelombang Berdiri pada Kabel Koaksial Menggunakan Dioda Detector 1N4148”.

\section{METODE PENELITIAN}

Metode penelitian yang digunakan adalah metode penelitian eksperimental. Variabel bebas dalam penelitian ini yaitu panjang fisis kabel koaksial, jumlah titik pengambilan data, dan panjang gelombang untuk pengambilan data. Variabel terkontrol dalam penelitian ini yaitu dioda detector 1N4148, kabel koaksial $50 \Omega$ dan frekuensi masukan. Sedangkan variabel terikat dalam penelitian ini yaitu gelombang berdiri. Tujuan dari penelitian dengan sifat eksperimental maksudnya adalah dengan mencoba alat yang sudah dirancang untuk dapat dianalisa. Pada penelitian yang akan dilakukan bertujuan untuk merancang sebuah Rancang Bangun Pendeteksi Gelombang Berdiri Pada Kabel Koaksial Menggunakan Dioda Detector 1N4148.

\section{A. Tahapan Penelitian}

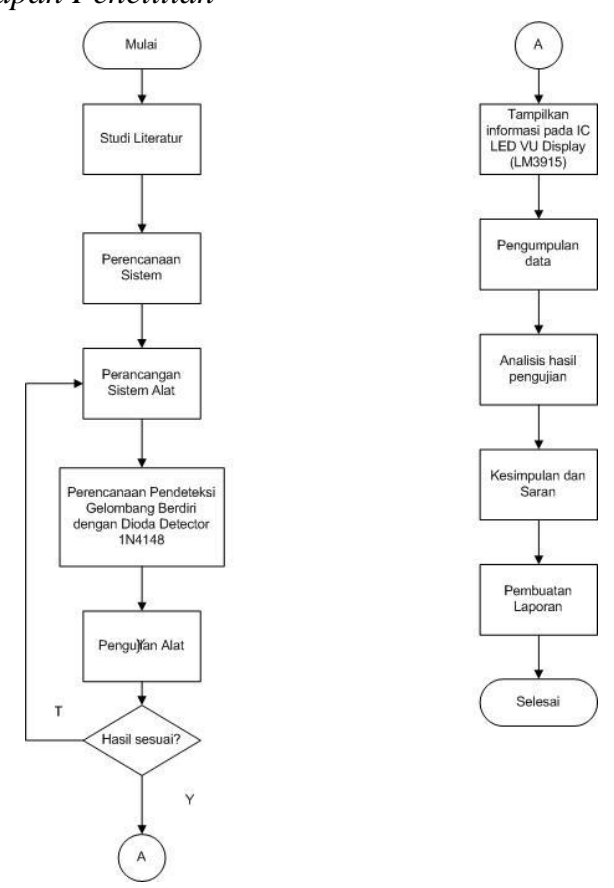

Gambar 1. Flowchart rancangan penelitian

\section{B. Perancangan Sistem}

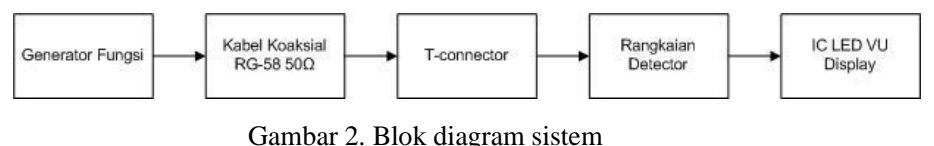

Setiap bagian tersebut memiliki perannya masing-masing.

Keterangan untuk tiap bagian adalah sebagaimana berikut:

1. Generator Fungsi

Generator Fungsi berperan sebagai masukan sinyal yang dibutuhkan. Dimana pada desain perangkat tersebut generator fungsi dihubungkan dengan kabel koaksial.

2. Kabel Koaksial RG-58 $50 \Omega$

Kabel koaksial berperan sebagai media transmisi sinyal pada generator fungsi. Kabel RG-58 dapat digunakan untuk frekuensi cukup tinggi. Pengurangan sinyalnya tergantung pada frekuensi, misalnya dari $10,8 \mathrm{~dB}$ per 100 m (3,3 dB per $100 \mathrm{kaki})$ pada $50 \mathrm{MHz}$ hingga 70,5 dB per $100 \mathrm{~m}(21,5 \mathrm{~dB}$ per $100 \mathrm{kaki})$ pada $1 \mathrm{GHz}$.

3. T-connector

T-connector berperan sebagai media penghubung sinyal yang ditransmisikan oleh kabel koaksial.

4. BNC connector male RG-58

BNC connector male RG-58 berperan sebagai media penyambung antara kabel koaksial dengan generator fungsi dan antar perpotongan pada kabel koaksial

5. Rangkaian Detector

Rangkaian Detector berperan sebagai rangkaian yang terdiri dari dioda detector $1 \mathrm{~N} 4148$ dan kapasitor $100 \mathrm{pF}$ dimana dioda detector 1N4148 yang akan berperan mendeteksi gelombang berdiri pada kabel koaksial.

6. IC LED VU Display (LM3915)

IC LED VU Display (LM3915) digunakan sebagai media yang menampilkan gelombang berdiri yang terdeteksi oleh rangkaian detector.

LM3915 adalah sirkuit terpadu monolitik yang mendeteksi tingkat tegangan analog dan mendorong sepuluh LED, LCD atau tampilan neon vakum, menyediakan layar analog $3 \mathrm{~dB} /$ langkah logaritmik. Satu pin mengubah tampilan dari grafik batang menjadi tampilan titik bergerak. Drive LED saat ini diatur dan dapat diprogram, sehingga tidak perlu lagi membatasi pengkodean saat ini. Seluruh sistem tampilan dapat beroperasi dari pasokan tunggal serendah $3 \mathrm{~V}$ atau setinggi $25 \mathrm{~V}$. IC berisi referensi tegangan yang dapat diatur dan pembagi tegangan sepuluh langkah yang akurat. Buffer input impedansi tinggi menerima sinyal turun ke tanah dan hingga di dalam $1.5 \mathrm{~V}$ dari suplai positif. Lebih lanjut, tidak perlu perlindungan terhadap input $\pm 35 \mathrm{~V}$. Input buffer drive 10 komparator individu yang direferensikan ke pembagi presisi. Akurasi biasanya lebih baik daripada $1 \mathrm{~dB}$ [3]. 


\section{Penentuan Prosedur}

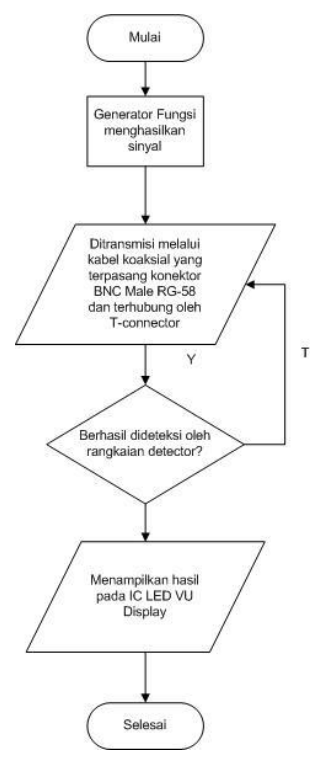

Gambar 3. Flowchart penentuan prosedur

Pada gambar 3 tersebut, generator fungsi akan menghasilkan sinyal. Setelah itu, sinyal akan ditransmisikan ke kabel koaksial yang sudah terpasang konektor BNC RG58. Sinyal yang diterima oleh kabel koaksial akan dihubungkan dengan T-connector. Sinyal yang terhubung oleh T-connector akan terdeteksi oleh rangkaian detector, dimana nantinya gelombang berdiri yang telah terdeteksi oleh rangkaian detector akan ditampilkan pada IC LED VU Display (LM3915).

\section{Implementasi Desain Perancangan pada Alat}

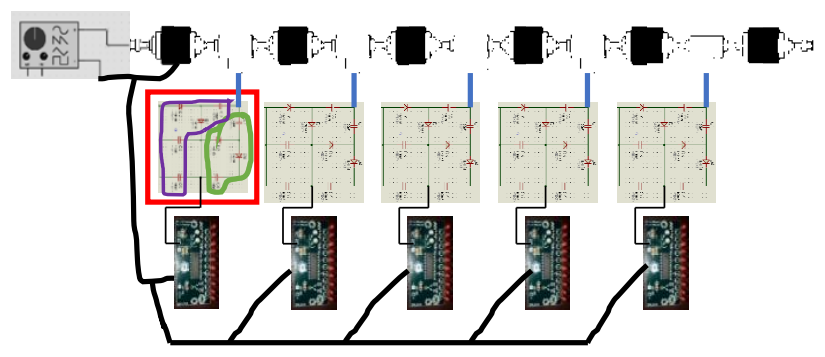

Gambar 4. Sistem skematik alat secara keseluruhan

Keterangan :

Menunjukkan ground dimana ground semua rangkaian (detector dan IC LED VU Display) menjadi satu yaitu selubung kabel coax menjadi grounding nya

Menunjukkan arus positif yang mengalir Menunjukkan rangkaian detektor Menunjukkan rangkaian pengali tegangan Menunjukkan gabungan detector dan pengali tegangan

\section{HASIL DAN PEMBAHASAN}

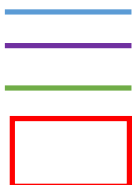

\section{A. Hasil Perakitan Alat}

Implementasi dari pembuatan sistem pendeteksi kurva gelombang berdiri terdapat sejumlah komponen yang terpasang seperti kabel koaksial RG-58 50 , konektor BNC RG-58, BNC T-connector, rangkain detector, dan IC LED VU Display yang dapat dilihat pada gambar 5.

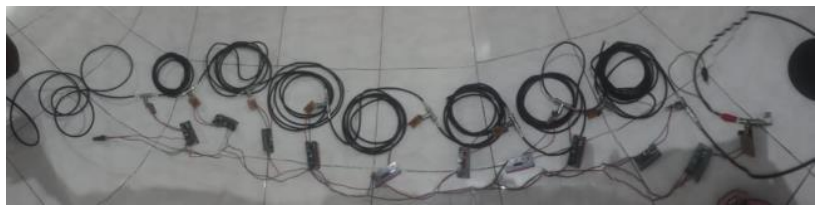

Gambar 5. Rangkaian alat secara keseluruhan

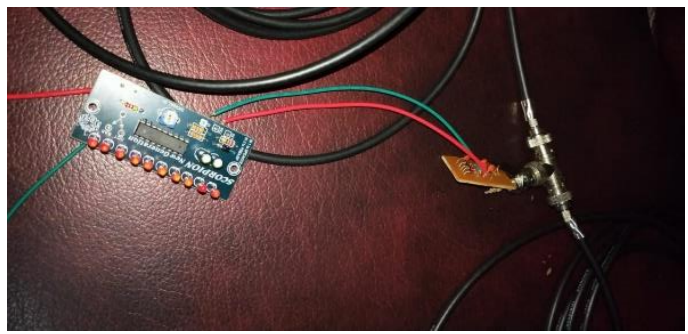

Gambar 6. Gabungan rangkaian detector dan IC LED VU display

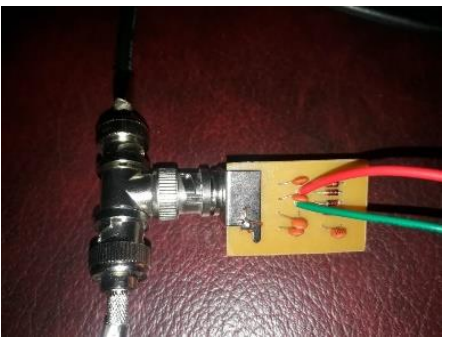

Gambar 7. Rangkaian Detector

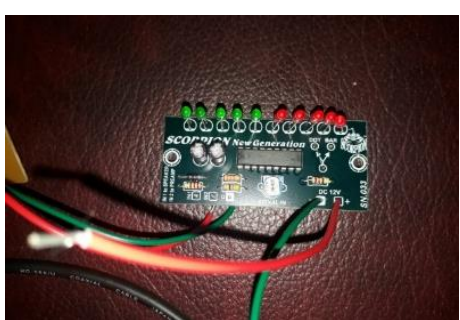

Gambar 8. IC LED VU Display 
Jurnal Jaringan Telekomunikasi, E-ISSN: 2654-6531, P-ISSN: 2407-0807 Vol. 11, No. 3 (2021) 145-150

B. Pengujian Gelombang Berdiri dengan Jarak untuk Beban yang Tetap

TABEL 1

Hasil Pengujian Gelombang BerdiRi Dalam Kondisi OPEN

\begin{tabular}{|c|c|c|c|c|c|c|c|c|c|c|c|c|}
\hline \multirow{2}{*}{$\begin{array}{c}\text { Frekuen } \\
\text { si Input }\end{array}$} & \multirow{2}{*}{$\begin{array}{l}\text { Tega } \\
\text { ngan } \\
\text { Input }\end{array}$} & \multirow{2}{*}{$\begin{array}{c}\text { Pan } \\
\text { jang } \\
\text { Gelom } \\
\text { bang }\end{array}$} & \multicolumn{10}{|c|}{ LED } \\
\hline & & & $\mathbf{0}$ & 1 & 2 & 3 & 4 & 5 & 6 & 7 & 8 & 9 \\
\hline \multirow{10}{*}{$2 \mathrm{MHz}$} & \multirow{10}{*}{$2 \mathrm{~V}$} & $\frac{1}{10} \lambda$ & $\mathrm{x}$ & $\sqrt{ }$ & $\sqrt{ }$ & $\sqrt{ }$ & $\sqrt{ }$ & $\sqrt{ }$ & $\sqrt{ }$ & $\mathrm{x}$ & $\mathrm{X}$ & $\mathrm{x}$ \\
\hline & & $\frac{2}{10} \lambda$ & $\mathrm{x}$ & $\mathrm{X}$ & $\sqrt{ }$ & $\sqrt{ }$ & $\sqrt{ }$ & $\sqrt{ }$ & $\sqrt{ }$ & $\mathrm{x}$ & $\mathrm{X}$ & $\mathrm{x}$ \\
\hline & & $\frac{3}{10} \lambda$ & $\mathrm{x}$ & $\sqrt{ }$ & $\sqrt{ }$ & $\sqrt{ }$ & $\sqrt{ }$ & $\sqrt{ }$ & $\sqrt{ }$ & $\sqrt{ }$ & $\mathrm{x}$ & $\mathrm{x}$ \\
\hline & & $\frac{4}{10} \lambda$ & $\mathrm{x}$ & $\mathrm{X}$ & $\mathrm{X}$ & $\mathrm{x}$ & $\mathrm{x}$ & $\sqrt{ }$ & $\sqrt{ }$ & $\mathrm{X}$ & $\mathrm{X}$ & $\mathrm{x}$ \\
\hline & & $\frac{5}{10} \lambda$ & $\mathrm{x}$ & $\mathrm{X}$ & $\mathrm{x}$ & $\mathrm{x}$ & $\mathrm{x}$ & $\sqrt{ }$ & $\sqrt{ }$ & $\mathrm{x}$ & $\sqrt{ }$ & $\sqrt{ }$ \\
\hline & & $\frac{6}{10} \lambda$ & $\mathrm{X}$ & $\mathrm{X}$ & $\mathrm{X}$ & $\mathrm{x}$ & $\sqrt{ }$ & $\sqrt{ }$ & $\sqrt{ }$ & $\sqrt{ }$ & $\mathrm{X}$ & $\mathrm{x}$ \\
\hline & & $\frac{7}{10} \lambda$ & $\mathrm{X}$ & $\mathrm{X}$ & $\mathrm{X}$ & $\mathrm{x}$ & $\mathrm{X}$ & $\mathrm{x}$ & $\sqrt{ }$ & $\sqrt{ }$ & $\sqrt{ }$ & $\sqrt{ }$ \\
\hline & & $\frac{8}{10} \lambda$ & $\mathrm{x}$ & $\mathrm{X}$ & $\mathrm{X}$ & $\mathrm{x}$ & $\mathrm{x}$ & $\mathrm{X}$ & $\mathrm{x}$ & $\sqrt{ }$ & $\sqrt{ }$ & $\sqrt{ }$ \\
\hline & & $\frac{9}{10} \lambda$ & $\mathrm{x}$ & $\mathrm{X}$ & $\mathrm{X}$ & $\mathrm{x}$ & $\sqrt{ }$ & $\mathrm{x}$ & $\sqrt{ }$ & $\sqrt{ }$ & $\sqrt{ }$ & $\sqrt{ }$ \\
\hline & & $\frac{10}{10} \lambda$ & $\mathrm{X}$ & X & X & $\mathrm{x}$ & $\mathrm{x}$ & $\mathrm{X}$ & $\sqrt{ }$ & $\sqrt{ }$ & $\sqrt{ }$ & $\sqrt{ }$ \\
\hline
\end{tabular}

\section{Keterangan :}

$\checkmark$ berarti lampu led menyala (kondisi 1)

$\mathbf{x}$ berarti lampu led mati (kondisi 0 )

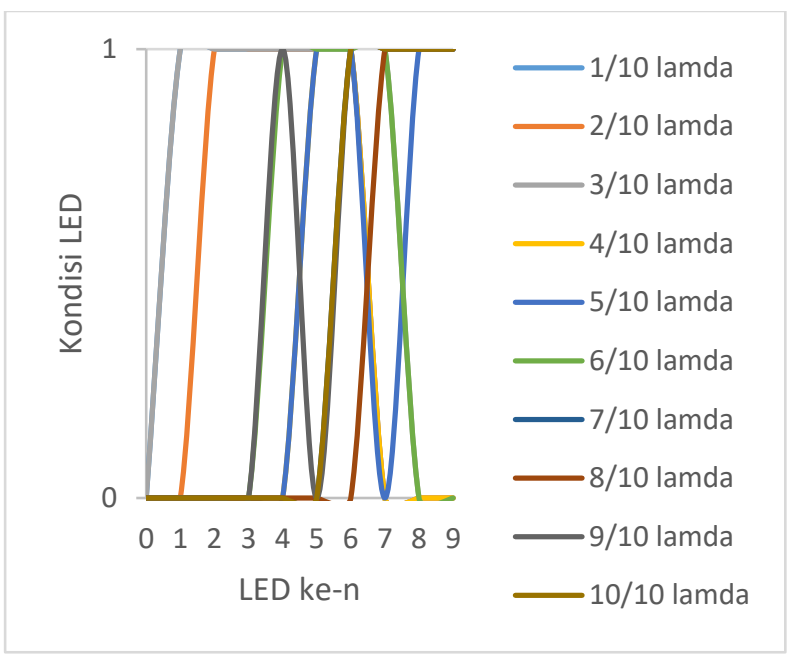

Gambar 9. Grafik pengujian gelombang berdiri dalam kondisi open

Tabel 1 Pengujian gelombang berdiri dalam kondisi open menunjukkan perbandingan kondisi LED pada panjang tertentu $(\lambda)$ dengan frekuensi input dan tegangan input yang telah ditentukan, terlihat bahwa gelombang berdiri dengan kondisi open muncul pada panjang tertentu dimana kurva tersebut dimulai dalam kondisi gelombang berada pada puncak (tegangan maksimum) lalu dilanjutkan dengan kondisi gelombang pada titik minimal. Kondisi tersebut terjadi secara berulang.
TABEL II

Hasil PenguJian Gelombang BeRdiRI DALAM KoNDISI SHORT

\begin{tabular}{|c|c|c|c|c|c|c|c|c|c|c|c|c|}
\hline \multirow{2}{*}{$\begin{array}{c}\text { Frekuen } \\
\text { si Input }\end{array}$} & \multirow{2}{*}{$\begin{array}{c}\text { Tega } \\
\text { ngan } \\
\text { Input }\end{array}$} & \multirow{2}{*}{$\begin{array}{c}\text { Pan } \\
\text { jang } \\
\text { Gelom } \\
\text { bang } \\
\end{array}$} & \multicolumn{10}{|c|}{ LED } \\
\hline & & & 0 & 1 & 2 & 3 & 4 & 5 & 6 & 7 & 8 & 9 \\
\hline \multirow{10}{*}{$2 \mathrm{MHz}$} & \multirow{10}{*}{$2 \mathrm{~V}$} & $\frac{1}{10} \lambda$ & $\sqrt{ }$ & $\sqrt{ }$ & $\mathrm{x}$ & $\mathrm{x}$ & $\mathrm{X}$ & $\mathrm{X}$ & $\mathrm{x}$ & $\mathrm{x}$ & $\mathrm{x}$ & $\mathrm{X}$ \\
\hline & & $\frac{2}{10} \lambda$ & $\mathrm{X}$ & $\mathrm{X}$ & $\mathrm{x}$ & $\mathrm{x}$ & $\mathrm{X}$ & $\mathrm{X}$ & $\sqrt{ }$ & $\sqrt{ }$ & $\mathrm{x}$ & $\mathrm{X}$ \\
\hline & & $\frac{3}{10} \lambda$ & $\mathrm{X}$ & $\sqrt{ }$ & $\sqrt{ }$ & $\mathrm{x}$ & $\mathrm{x}$ & $\mathrm{x}$ & $\mathrm{x}$ & $\mathrm{x}$ & $\mathrm{x}$ & $\mathrm{x}$ \\
\hline & & $\frac{4}{10} \lambda$ & $\mathrm{X}$ & $\sqrt{ }$ & $\mathrm{x}$ & $\mathrm{x}$ & $\mathrm{X}$ & $\sqrt{ }$ & $\sqrt{ }$ & $\mathrm{x}$ & $\sqrt{ }$ & $\sqrt{ }$ \\
\hline & & $\frac{5}{10} \lambda$ & $\mathrm{X}$ & $\mathrm{X}$ & $\mathrm{x}$ & $\mathrm{x}$ & $\mathrm{x}$ & $\sqrt{ }$ & $\sqrt{ }$ & $\sqrt{ }$ & $\mathrm{x}$ & $\mathrm{x}$ \\
\hline & & $\frac{6}{10} \lambda$ & $\mathrm{X}$ & $\mathrm{x}$ & $\mathrm{x}$ & $\mathrm{x}$ & $\mathrm{x}$ & $\mathrm{x}$ & $\sqrt{ }$ & $\sqrt{ }$ & $\sqrt{ }$ & $\sqrt{ }$ \\
\hline & & $\frac{7}{10} \lambda$ & $\mathrm{X}$ & $\mathrm{x}$ & $\mathrm{x}$ & $\mathrm{x}$ & $\sqrt{ }$ & $\sqrt{ }$ & $\sqrt{ }$ & $\sqrt{ }$ & $\sqrt{ }$ & $\sqrt{ }$ \\
\hline & & $\frac{8}{10} \lambda$ & $\mathrm{x}$ & $\mathrm{X}$ & $\mathrm{x}$ & $\mathrm{x}$ & $\mathrm{X}$ & $\mathrm{x}$ & $\mathrm{x}$ & $\sqrt{ }$ & $\sqrt{ }$ & $\sqrt{ }$ \\
\hline & & $\frac{9}{10} \lambda$ & $\mathrm{x}$ & $\mathrm{x}$ & $\mathrm{x}$ & $\mathrm{x}$ & $\mathrm{x}$ & $\mathrm{x}$ & $\sqrt{ }$ & $\sqrt{ }$ & $\sqrt{ }$ & $\sqrt{ }$ \\
\hline & & $\frac{10}{10} \lambda$ & $\mathrm{X}$ & $\mathrm{x}$ & $\mathrm{X}$ & $\sqrt{ }$ & $\sqrt{ }$ & $\sqrt{ }$ & $\sqrt{ }$ & $\sqrt{ }$ & $\sqrt{ }$ & $\mathrm{x}$ \\
\hline
\end{tabular}

Keterangan :

$\checkmark$ berarti lampu led menyala (kondisi 1)

$\boldsymbol{x}$ berarti lampu led mati (kondisi 0 )

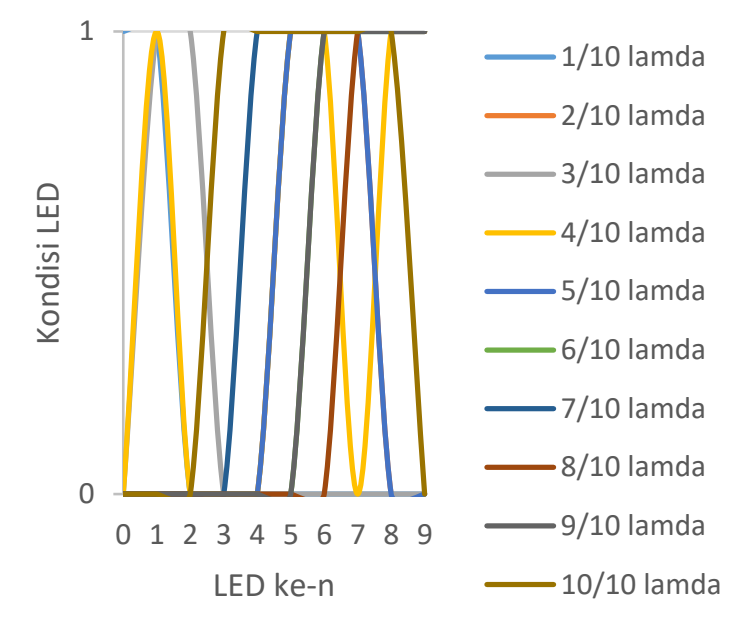

Gambar 10. Grafik pengujian gelombang berdiri dalam kondisi short

Tabel 2 Pengujian gelombang berdiri dalam kondisi short menunjukkan perbandingan kondisi LED pada panjang tertentu $(\lambda)$ dengan frekuensi input dan tegangan input yang telah ditentukan, terlihat bahwa gelombang berdiri dengan kondisi short muncul pada panjang tertentu dimana kurva tersebut dimulai dalam kondisi gelombang berada pada titik minimal (tegangan minimum) lalu dilanjutkan dengan kondisi gelombang pada titik maksimal (tegangan maksimum). Kondisi tersebut terjadi secara berulang. 
Jurnal Jaringan Telekomunikasi, E-ISSN: 2654-6531, P-ISSN: 2407-0807 Vol. 11, No. 3 (2021) 145-150

TABEL III

Hasil Pengujian Gelombang BeRdiRi Dalam Kondisi Match $\left(\mathbf{R}_{\mathbf{L}}=\right.$ $50 \Omega)$

\begin{tabular}{|c|c|c|c|c|c|c|c|c|c|c|c|c|}
\hline \multirow{2}{*}{$\begin{array}{l}\text { Frekuen } \\
\text { si Input }\end{array}$} & \multirow{2}{*}{$\begin{array}{c}\text { Tega } \\
\text { ngan } \\
\text { Input }\end{array}$} & \multirow{2}{*}{$\begin{array}{c}\text { Pan } \\
\text { jang } \\
\text { Gelom } \\
\text { bang }\end{array}$} & \multicolumn{10}{|c|}{ LED } \\
\hline & & & 0 & 1 & 2 & 3 & 4 & 5 & 6 & 7 & 8 & 9 \\
\hline \multirow{10}{*}{$2 \mathrm{MHz}$} & \multirow{10}{*}{$2 \mathrm{~V}$} & $\frac{1}{10} \lambda$ & $\mathrm{X}$ & $\mathrm{x}$ & $\mathrm{x}$ & $\mathrm{X}$ & $\mathrm{X}$ & $\mathrm{X}$ & $\mathrm{x}$ & $\mathrm{X}$ & $\mathrm{X}$ & $\mathrm{X}$ \\
\hline & & $\frac{2}{10} \lambda$ & $\mathrm{X}$ & $\mathrm{x}$ & $\mathrm{X}$ & $\mathrm{X}$ & X & $\mathrm{X}$ & $\sqrt{ }$ & $\sqrt{ }$ & $\mathrm{X}$ & $\mathrm{x}$ \\
\hline & & $\frac{-}{10} \lambda$ & $\mathrm{X}$ & $\mathrm{x}$ & $\mathrm{X}$ & $\mathrm{X}$ & $\mathrm{X}$ & $\mathrm{X}$ & $\sqrt{ }$ & $\sqrt{ }$ & $\sqrt{ }$ & $\sqrt{ }$ \\
\hline & & $\frac{4}{10} \lambda$ & $\mathrm{X}$ & $\mathrm{x}$ & $\mathrm{x}$ & $\mathrm{X}$ & $\mathrm{X}$ & $\mathrm{X}$ & $\mathrm{x}$ & $\mathrm{X}$ & $\mathrm{X}$ & $\mathrm{x}$ \\
\hline & & $\frac{5}{10} \lambda$ & $X$ & $\mathrm{x}$ & $\mathrm{x}$ & $\mathrm{X}$ & $\mathrm{X}$ & $\mathrm{X}$ & $\mathrm{x}$ & $\mathrm{X}$ & X & $\mathrm{X}$ \\
\hline & & $\frac{6}{10} \lambda$ & $\mathrm{X}$ & $\mathrm{x}$ & $\mathrm{x}$ & $\mathrm{X}$ & $X$ & $\mathrm{X}$ & $\mathrm{X}$ & $\mathrm{X}$ & $\mathrm{X}$ & $\sqrt{ }$ \\
\hline & & $\frac{1}{10} \lambda$ & $X$ & $\mathrm{x}$ & $\mathrm{x}$ & $\mathrm{X}$ & $\mathrm{X}$ & $\mathrm{x}$ & $\mathrm{x}$ & $\mathrm{x}$ & $\mathrm{X}$ & $\mathrm{X}$ \\
\hline & & $\frac{0}{10} \lambda$ & $\mathrm{X}$ & $\mathrm{x}$ & $\mathrm{x}$ & $\mathrm{X}$ & $\mathrm{X}$ & $\mathrm{X}$ & $\mathrm{X}$ & $\mathrm{x}$ & $\mathrm{X}$ & $\mathrm{X}$ \\
\hline & & $\frac{9}{10} \lambda$ & $\mathrm{X}$ & $\mathrm{x}$ & $\sqrt{ }$ & $\sqrt{ }$ & $\sqrt{ }$ & $\mathrm{x}$ & $\sqrt{ }$ & $\sqrt{ }$ & $\mathrm{X}$ & $\mathrm{X}$ \\
\hline & & $\frac{10}{10} \lambda$ & $\mathrm{X}$ & $\mathrm{X}$ & $\mathrm{x}$ & $\mathrm{X}$ & $\mathrm{X}$ & $\mathrm{X}$ & $\mathrm{X}$ & $\mathrm{X}$ & $\mathrm{X}$ & $\mathrm{x}$ \\
\hline
\end{tabular}

Keterangan :

$\checkmark$ berarti lampu led menyala (kondisi 1)

$\mathbf{x}$ berarti lampu led mati (kondisi 0 )

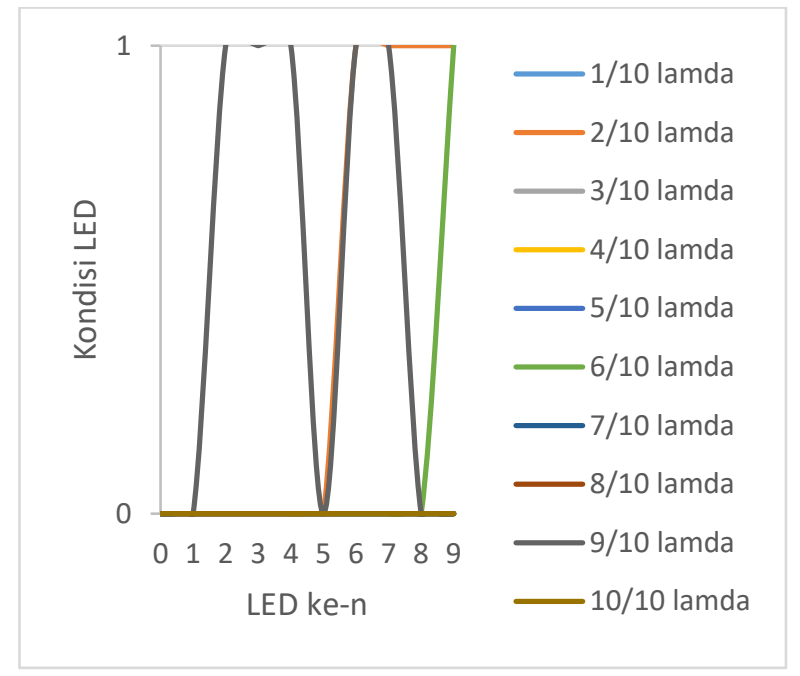

Gambar 11. Grafik pengujian gelombang berdiri dalam kondisi match

$$
\left(R_{l}=50 \Omega\right)
$$

Tabel 3 Pengujian gelombang berdiri dalam kondisi match $\left(\boldsymbol{R}_{\boldsymbol{l}}=\mathbf{5 0} \Omega\right)$ menunjukkan perbandingan kondisi LED pada panjang tertentu $(\lambda)$ dengan frekuensi input dan tegangan input yang telah ditentukan, terlihat bahwa ada beberapa LED yang menyala di panjang tertentu dengan kondisi match $\left(\boldsymbol{R}_{\boldsymbol{l}}=\mathbf{5 0} \Omega\right)$, tetapi LED yang menyala tersebut tidak membentuk kurva gelombang berdiri karena apabila kondisi load dan feeder dalam kondisi match, maka gelombang yang masuk pada kabel koaksial tidak terjadi pemantulan.menyala.
TABEL IV

Hasil Pengujian Gelombang BerdiRi Dalam Kondisi Mismatch $\left(R_{l}<50 \Omega\right)$

\begin{tabular}{|c|c|c|c|c|c|c|c|c|c|c|c|c|}
\hline \multirow{2}{*}{$\begin{array}{c}\text { Frekuen } \\
\text { si Input }\end{array}$} & \multirow{2}{*}{$\begin{array}{c}\text { Tega } \\
\text { ngan } \\
\text { Input }\end{array}$} & \multirow{2}{*}{$\begin{array}{c}\text { Pan } \\
\text { jang } \\
\text { Gelom } \\
\text { bang } \\
\end{array}$} & \multicolumn{10}{|c|}{ LED } \\
\hline & & & 0 & 1 & 2 & 3 & 4 & 5 & 6 & 7 & 8 & 9 \\
\hline \multirow{10}{*}{$2 \mathrm{MHz}$} & \multirow{10}{*}{$2 \mathrm{~V}$} & $\frac{1}{10} \lambda$ & $\mathrm{x}$ & $\mathrm{x}$ & $\mathrm{x}$ & $\sqrt{ }$ & $\sqrt{ }$ & $\sqrt{ }$ & $\sqrt{ }$ & $\mathrm{x}$ & $\mathrm{x}$ & $\mathrm{x}$ \\
\hline & & & $\mathrm{X}$ & $\mathrm{x}$ & $\mathrm{x}$ & $\mathrm{x}$ & $\mathrm{x}$ & $\mathrm{x}$ & $\mathrm{x}$ & $\sqrt{ }$ & $\sqrt{ }$ & $\sqrt{ }$ \\
\hline & & $\frac{3}{10} \lambda$ & $\mathrm{X}$ & $\sqrt{ }$ & $\sqrt{ }$ & $\sqrt{ }$ & $\mathrm{x}$ & $\mathrm{X}$ & $\mathrm{x}$ & $\mathrm{X}$ & $\mathrm{x}$ & $\mathrm{x}$ \\
\hline & & $\frac{4}{10} \lambda$ & $\mathrm{x}$ & $\mathrm{x}$ & $\mathrm{x}$ & $\mathrm{x}$ & $\mathrm{x}$ & $\sqrt{ }$ & $\sqrt{ }$ & $\mathrm{x}$ & $\sqrt{ }$ & $\sqrt{ }$ \\
\hline & & $\frac{5}{10} \lambda$ & $\mathrm{x}$ & $\mathrm{x}$ & $\mathrm{x}$ & $\mathrm{x}$ & $\sqrt{ }$ & $\sqrt{ }$ & $\sqrt{ }$ & $\sqrt{ }$ & $\mathrm{x}$ & $\mathrm{x}$ \\
\hline & & $\frac{6}{10} \lambda$ & $\mathrm{x}$ & $\mathrm{x}$ & $\mathrm{x}$ & $\mathrm{x}$ & $\mathrm{x}$ & $\mathrm{x}$ & $\mathrm{x}$ & $\sqrt{ }$ & $\sqrt{ }$ & $\sqrt{ }$ \\
\hline & & $\frac{7}{10} \lambda$ & $\mathrm{x}$ & $\mathrm{x}$ & $\mathrm{x}$ & $\mathrm{x}$ & $\mathrm{x}$ & $\mathrm{x}$ & $\mathrm{x}$ & $\sqrt{ }$ & $\sqrt{ }$ & $\mathrm{x}$ \\
\hline & & $\frac{8}{10} \lambda$ & $\mathrm{x}$ & $\mathrm{x}$ & $\sqrt{ }$ & $\sqrt{ }$ & $\sqrt{ }$ & $\sqrt{ }$ & $\sqrt{ }$ & $\mathrm{X}$ & $\mathrm{x}$ & $\mathrm{X}$ \\
\hline & & $\frac{9}{10} \lambda$ & $\mathrm{x}$ & $\sqrt{ }$ & $\sqrt{ }$ & $\sqrt{ }$ & $\sqrt{ }$ & $\mathrm{x}$ & $\mathrm{x}$ & $\mathrm{x}$ & $\mathrm{x}$ & $\mathrm{x}$ \\
\hline & & $\frac{10}{10} \lambda$ & $\sqrt{ }$ & $\sqrt{ }$ & $\sqrt{ }$ & $\sqrt{ }$ & $\sqrt{ }$ & $\sqrt{ }$ & $\mathrm{x}$ & $\mathrm{X}$ & $\mathrm{X}$ & $\mathrm{x}$ \\
\hline
\end{tabular}

Keterangan :

$\checkmark$ berarti lampu led menyala (kondisi 1)

$\mathbf{x}$ berarti lampu led mati (kondisi 0)

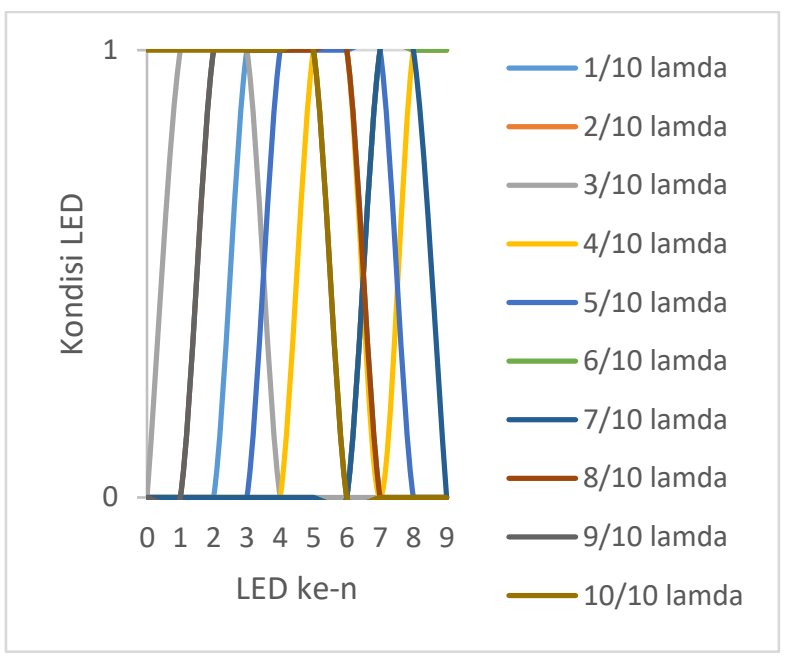

Gambar 12. Grafik pengujian gelombang berdiri dalam kondisi mismatch $\left(R_{l}<50 \Omega\right)$

Tabel 4 Pengujian gelombang berdiri dalam kondisi mismatch $\left(\mathbf{R}_{\mathbf{l}}<\mathbf{5 0} \Omega\right)$ menunjukkan perbandingan kondisi LED pada panjang tertentu $(\lambda)$ dengan frekuensi input dan tegangan input yang telah ditentukan, terlihat bahwa gelombang berdiri dengan kondisi mismatch $\left(\mathbf{R}_{\mathbf{l}}<\mathbf{5 0} \Omega\right)$ muncul pada panjang tertentu dimana dimulai dari titik $4 / 10$ $\lambda$ hingga $7 / 10 \lambda$. Hal ini disebabkan karena load dan feeder dalam kondisi mismatch $\left(\mathbf{R}_{\mathbf{1}}<\mathbf{5 0} \Omega\right)$ sehingga apabila ada gelombang datang akan terjadi pemantulan dan menimbulkan terjadinya penumpukan serta akan muncul gelombang berdiri. 
TABEL V

Hasil PENGUjian Gelombang BERDiRi Dalam Kondisi Mismatch $\left(R_{l}>50 \Omega\right)$

\begin{tabular}{|c|c|c|c|c|c|c|c|c|c|c|c|c|}
\hline \multirow{2}{*}{$\begin{array}{l}\text { Frekuen } \\
\text { si Input }\end{array}$} & \multirow{2}{*}{$\begin{array}{l}\text { Tega } \\
\text { ngan } \\
\text { Input }\end{array}$} & \multirow{2}{*}{$\begin{array}{c}\text { Pan } \\
\text { jang } \\
\text { Gelom } \\
\text { bang }\end{array}$} & \multicolumn{10}{|c|}{ LED } \\
\hline & & & 0 & 1 & 2 & 3 & 4 & 5 & 6 & 7 & 8 & 9 \\
\hline \multirow{10}{*}{$2 \mathrm{MHz}$} & \multirow{10}{*}{$2 \mathrm{~V}$} & $\frac{1}{10} \lambda$ & $\mathrm{X}$ & $\mathrm{x}$ & $\mathrm{x}$ & $\mathrm{X}$ & $\sqrt{ }$ & $\sqrt{ }$ & $\sqrt{ }$ & $\sqrt{ }$ & $\sqrt{ }$ & $\mathrm{x}$ \\
\hline & & & $\mathrm{X}$ & $\mathrm{x}$ & $\mathrm{x}$ & $\mathrm{X}$ & $\mathrm{X}$ & $\mathrm{x}$ & $\sqrt{ }$ & $\sqrt{ }$ & $\sqrt{ }$ & $\mathrm{X}$ \\
\hline & & & $\mathrm{X}$ & $\mathrm{x}$ & $\mathrm{x}$ & $\mathrm{X}$ & $\mathrm{x}$ & $\sqrt{ }$ & $\sqrt{ }$ & $\mathrm{X}$ & $\sqrt{ }$ & $\sqrt{ }$ \\
\hline & & $\frac{4}{10} \lambda$ & $\mathrm{x}$ & $\mathrm{x}$ & $\mathrm{x}$ & $\mathrm{X}$ & $\sqrt{ }$ & $\sqrt{ }$ & $\mathrm{x}$ & $\sqrt{ }$ & $\sqrt{ }$ & $\mathrm{X}$ \\
\hline & & $\frac{5}{10} \lambda$ & $\mathrm{X}$ & $\mathrm{x}$ & $\mathrm{x}$ & $\mathrm{X}$ & $\sqrt{ }$ & $\sqrt{ }$ & $\sqrt{ }$ & $\sqrt{ }$ & $\mathrm{X}$ & $\mathrm{X}$ \\
\hline & & $\frac{6}{10} \lambda$ & $\mathrm{X}$ & $\mathrm{x}$ & $\mathrm{x}$ & $\mathrm{X}$ & $\mathrm{x}$ & $\mathrm{x}$ & $\mathrm{x}$ & $\mathrm{X}$ & $\sqrt{ }$ & $\sqrt{ }$ \\
\hline & & $\frac{7}{10} \lambda$ & $\mathrm{X}$ & $\mathrm{x}$ & $\mathrm{x}$ & $\mathrm{X}$ & $\mathrm{x}$ & $\sqrt{ }$ & $\sqrt{ }$ & $\sqrt{ }$ & $\sqrt{ }$ & $\sqrt{ }$ \\
\hline & & $\frac{8}{10} \lambda$ & $\mathrm{X}$ & $\mathrm{x}$ & $\mathrm{x}$ & $\mathrm{X}$ & $\mathrm{x}$ & $\mathrm{X}$ & $\mathrm{x}$ & $\sqrt{ }$ & $\sqrt{ }$ & $\sqrt{ }$ \\
\hline & & $\frac{9}{10} \lambda$ & $\mathrm{X}$ & $\mathrm{X}$ & $\mathrm{x}$ & $\mathrm{X}$ & $\mathrm{x}$ & $\mathrm{X}$ & $\sqrt{ }$ & $\sqrt{ }$ & $\sqrt{ }$ & $\sqrt{ }$ \\
\hline & & $\frac{10}{10} \lambda$ & $\mathrm{X}$ & $\mathrm{x}$ & $\sqrt{ }$ & $\sqrt{ }$ & $\sqrt{ }$ & $\sqrt{ }$ & $\sqrt{ }$ & $x$ & $\mathrm{X}$ & $X$ \\
\hline
\end{tabular}

Keterangan :

$\checkmark$ berarti lampu led menyala (kondisi 1)

$\mathbf{x}$ berarti lampu led mati (kondisi 0)

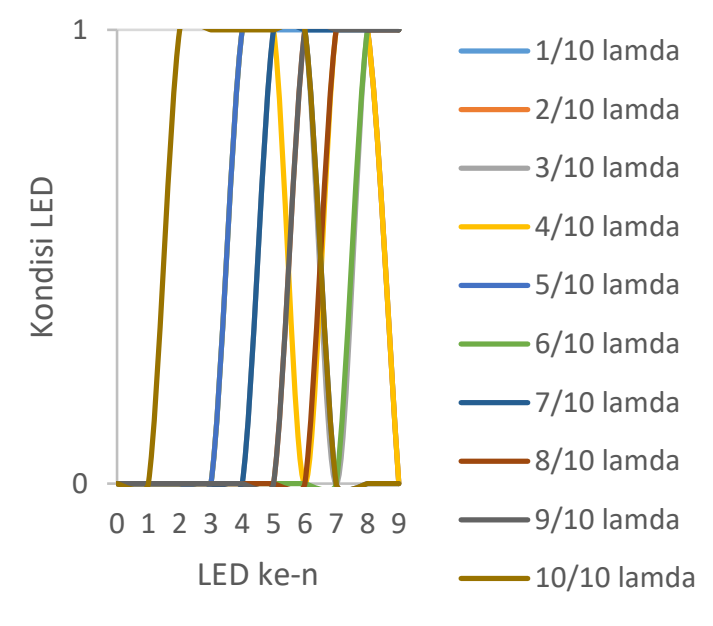

Gambar 13. Grafik pengujian gelombang berdiri dalam kondisi mismatch $\left(R_{l}>50 \Omega\right)$

Tabel 5 Pengujian gelombang berdiri dalam kondisi mismatch $\left(\mathbf{R}_{\mathbf{l}}>\mathbf{5 0} \Omega\right)$ menunjukkan perbandingan kondisi LED pada panjang tertentu $(\lambda)$ dengan frekuensi input dan tegangan input yang telah ditentukan, terlihat bahwa gelombang berdiri dengan kondisi mismatch $\left(\mathbf{R}_{\mathbf{l}}>\mathbf{5 0} \Omega\right)$ muncul pada panjang tertentu dimana dimulai dari titik $7 / 10$ $\lambda$ dan $8 / 10 \lambda$. Hal ini disebabkan karena load dan feeder dalam kondisi mismatch $\left(\mathbf{R}_{\mathbf{l}}>\mathbf{5 0} \Omega\right)$ sehingga apabila ada gelombang datang akan terjadi pemantulan dan menimbulkan terjadinya penumpukan serta akan muncul gelombang berdiri.

\section{KESIMPULAN}

1. Hasil penerapan dari implementasi sistem pendeteksi kurva gelombang berdiri pada kabel koaksial dilakukan dengan menggunakan rangkaian detector dan IC LED VU Display sebagai media tampilan dari output rangkaian detector.

2. Pengontrolan frekuensi dan tegangan input telah ditentukan terlebih dahulu yaitu $2 \mathrm{MHz}$ dan $2 \mathrm{~V}$ pada generator fungsi sebagai masukan sinyal, dalam pengujian sistem ini diperoleh bahwa gelombang berdiri muncul pada kondisi mismatch $R l<50 \Omega$ dan kondisi mismatch $R l>50 \Omega$.

3. Gelombang berdiri dalam kondisi mismatch $R l<50 \Omega$ diperoleh pada titik $4 / 10 \lambda$ hingga $7 / 10 \lambda$, dalam kondisi mismatch $R l>50 \Omega$ pada titik $7 / 10 \lambda$ dan $8 / 10 \lambda$, dalam kondisi match tidak ada gelombang yang dipantulkan.

\section{REFERENSI}

[1] B. A. B. Ii, "Bab ii saluran transmisi 2.1,” pp. 15-34.

A. H. Rambe and Suryanto, "Analisis Pengaruh Frekuensi Terhadap Redaman Pada Kabel Koaksial," Singuda Ensikom, vol. 2, no. 3, pp. 90-95, 2013.

[3] 